Table 2 REE by isotope dilution

\begin{tabular}{|c|c|c|c|c|c|c|c|c|c|}
\hline Sample & $\mathrm{La}$ & $\mathrm{Ce}$ & Nd & $\mathrm{Sm}$ & $\mathrm{Eu}$ & $\mathrm{Gd}$ & Dy & $\mathrm{Er}$ & Yb \\
\hline $42162 \mathrm{CPX}^{*}$ & 0.90 & 3.60 & 5.33 & 2.00 & 0.69 & 2.60 & 2.75 & 1.37 & 1.00 \\
\hline $42158 \mathrm{CPX}$ & 0.59 & 2.66 & 3.57 & 1.36 & 0.47 & 1.79 & 1.78 & 0.90 & 0.68 \\
\hline 42157 CPX & 0.83 & 3.73 & 5.34 & 2.15 & 0.75 & 2.92 & 2.99 & 1.54 & 1.20 \\
\hline $42156 \mathrm{CPX}$ & - & 2.94 & 3.99 & 1.54 & 0.48 & - & - & - & 0.81 \\
\hline 42154 CPX & 0.44 & 2.06 & 2.77 & 1.08 & 0.38 & 1.42 & 1.45 & 0.71 & 0.55 \\
\hline 42149 CPX & 0.79 & 2.77 & 3.790 & 1.48 & 0.49 & 1.95 & - & 0.94 & 0.83 \\
\hline 42144 CPX & 0.79 & 3.63 & 4.79 & 1.83 & 0.58 & 2.42 & - & 1.29 & 1.000 \\
\hline 42142 CPX & - & 3.78 & 4.57 & 1.75 & 0.56 & 2.29 & 一 & 1.29 & 0.97 \\
\hline $41596 \mathrm{CPX}$ & 0.77 & 3.26 & 4.360 & 1.65 & 0.52 & 2.03 & - & 1.19 & 0.94 \\
\hline
\end{tabular}

From ref. 15 . Errors 2 s.e. are $1 \%$. CPX, clinopyroxene.

Table 2. The REE patterns are parallel, with variable, small, negative $\mathrm{Eu}$ anomalies. Because the patterns are parallel the total REE content ( $\sum \mathrm{REE}$ ) of the pyroxenes can be expressed in terms of one element, $\mathrm{Nd}$, for example. The variation of $\mathrm{Nd}$ through unit 9 (Fig. 2) is remarkably similar to ${ }^{87} \mathrm{Sr} /{ }^{86} \mathrm{Sr}$. Although $\mathrm{Nd}$ can increase in magma during fractionation, ${ }^{87} \mathrm{Sr} /{ }^{86} \mathrm{Sr}$ cannot, consequently, these variations represent the addition of a high $\mathrm{Nd}$, high ${ }^{87} \mathrm{Sr} /{ }^{86} \mathrm{Sr}$ contaminant. This addition is seen in the gabbros at the top of unit 9 and coincides with

Received 25 May; accepted 18 November 1983

1. DePaolo, D. \& Wasserburg, G. Geochim. cosmochim. Acta 43, 615-627 (1979).

2. James, D. E. Earth planet. Sci. Lett. 57, 47-62 (1982).

3. DePaolo, D. Earth planet. Sci. Lett. 53, 189-202 (1982)

4. Moorbath, S. \& Welke, H. Earth planet. Sci. Lett. 5, 217-230 (1969).

5. Moorbath, S. \& Thompson, R. N. J. Petrol. 21, 295-321 (1980).

6. Dickin, A. P. J. Petrol. 22, 155-189 (1980).

7. Brown, G. M. Phil. Trans. R. Soc. B240, 1-53 (1956). fractionation. The peridotites of unit 9 also seem to be contaminated. However, this contamination could be the result of magma mixing between the fresh magma influx and any contaminated magma left in the chamber.

I thank Drs M. F. Thirlwall, R. A. Cliff and B. M. Wilson for helpful discussion and criticism and Dr E. Condliffe for advice on the microprobe. Isotope work at Leeds is funded by the Royal Society and NERC, and this work was performed during the tenure of a NERC studentship.

8. Huppert, H. E. \& Sparks, R. S. J. Contr. Miner. Petrol. 75, 279-289 (1980).

9. Roeder, P. L. \& Emslie, R. F. Contr. Miner. Petrol. 29, 275-289 (1970),

10. Dunham, A. C. \& Wadsworth, W. J. Min. Mag. 42, 347-356 (1979).

11. Vollmer, R., et al. Geotherm. Res. 11, 317-327 (1981).

12. Sneeringer, M \& Hart, S. EOS $59,402(1978)$

13. Taylor, H. P. \& Forester, R. W. J. Petrol 20, 355-419 (1979).

14. Stosch, H. G., Cartson, R. W. \& Lugmair, G. W. Earth. planet. Sci. Lett. 47, 263-271 (1980).

15. Thirlwall, M. F., Chem. Geol. 35, 155-166 (1982).

\section{Oxygen isotope calibration of the onset of ice-rafting and history of glaciation in the North Atlantic region}

\author{
N. J. Shackleton*, J. Backman, H. Zimmerman, \\ D. V. Kent, M. A. Hall, D. G. Roberts, D. Schnitker, \\ J. G. Baldauf, A. Desprairies, R. Homrighausen, \\ P. Huddlestun, J. B. Keene, A. J. Kaltenback, \\ K. A. O. Krumsiek, A. C. Morton, \\ J. W. Murray \& J. Westberg-Smith
}

We report here that DSDP Site 552A, cored with the hydraulic piston corer on the west flank of Rockall Bank, recovered an undisturbed sequence of alternating white deep-sea carbonate oozes and dark-coloured layers that are rich in glacial debris. Oxygen isotope analysis of the sequence together with detailed nannofossil and palaeomagnetic stratigraphy shows that the first major horizon of ice-rafting occurred at about $2.4 \mathrm{Myr}$, and was preceded by a minor pulse of ice-rafting at about $2.5 \mathrm{Myr}$. The carbon isotope record shows that the site has been bathed by a water mass of similar characteristics to present-day North Atlantic deep water at least since $3.5 \mathrm{Myr}$.

Despite the concentration of members of the deep-sea drilling community around the North Atlantic, surprisingly few Deep Sea Drilling Project sites have been drilled that are suitable for even a cursory study of North Atlantic palaeoenvironments. Until recently the best sites in which to study the onset of glaciation around the North Atlantic were from DSDP Leg 12, sites 111 and 116, in which Berggren ${ }^{1}$ studied the stratigraphic

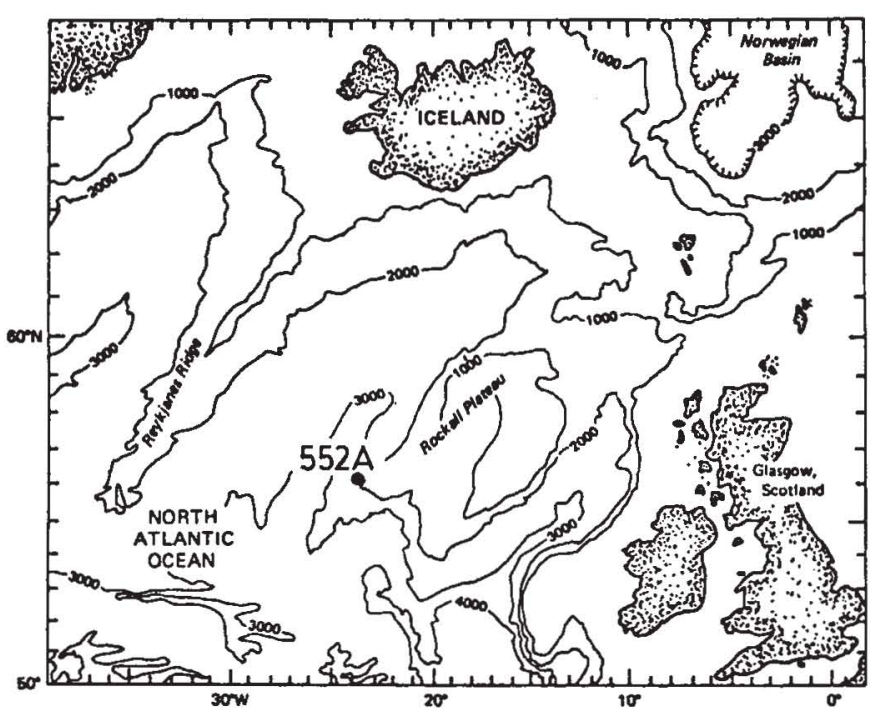

Fig. 1 Location map for Site $552 \mathrm{~A}\left(56^{\circ} 02.56^{\prime} \mathrm{N}, 23^{\circ} 13.38^{\prime} \mathrm{W}\right.$, $2,311 \mathrm{~m}$ water depth.

position of the earliest ice-rafted debris in the region and estimated its age at $3.0 \mathrm{Myr}\left(\mathrm{Backman}^{2}\right.$ re-examined this material and obtained a younger estimate of $2.5 \mathrm{Myr}$ ). Sediments from the Leg 12 sites were extensively disturbed by rotary drilling, and not suitable for detailed analysis of the palaeoenvironmental record. During Leg 81, the Glomar Challenger used the newly developed hydraulic piston corer (HPC) ${ }^{3}$ with considerable success, and in particular recovered a section from the west flank of Rockall Bank (Fig. 1) that is largely undisturbed.
*Authors' addresses: Godwin Laboratory for Quaternary Research, Free School Lane, Cambridge CB2 3RS (N.J.S.); Department of Geology, University of Stockholm, S. 10690 Stockholm, Sweden (J.B.): Department of Civil Engineering, Union College, Schenectady, New York 12308, USA (H.Z.); Lamond Doherty Geological Observatory of Columbia University, Palisades, New York 10964, USA (N.J.S., D.V.K.): British Petroleum (Overseas) Development Lid, Britannic House, Moorgate, London ECI, UK (D.G.R.); Department of Oceanography, University of Maine, Walpole, Maine 04573, USA (D.S.); United States Geological Survey, 345 Middlefield Road, Menlo Park, California 94025, USA (J.G.B.); Laboratoire de Géochimie des
Roches Sédimentaires, University of Paris XI, 91405 Orsay, France (A.D.); Laboratorium für Roches Sédimentaires, University of Paris XI, 91405 Orsay, France (A.D.); Laboratorium für 19 Martin Luther King Jr Drive, Atlanta, Georgia 30334, USA (P.H.); Department of Geology, University of Melbourne, Parkville, Victoria 3052, Australia (J.B.): Denver Research Center, Marathon Oil Co., 7400 South Broadway, Littieton, Colorado 80160, USA (A.J.K.); Geologisches Institut, Nussallee 8, D-53 Bonn 1, FRG (K.A.O.K.); Institute of Geological Sciences, Ring Road, Halton, Leeds LS15 8TQ, UK (A.C.M.); Department of Geology, University of Exeter, Exeter. UK (J.W.M.); Scripps Institution of Oceanography, La Jolia, California 92092, USA (J.W.-S.). 


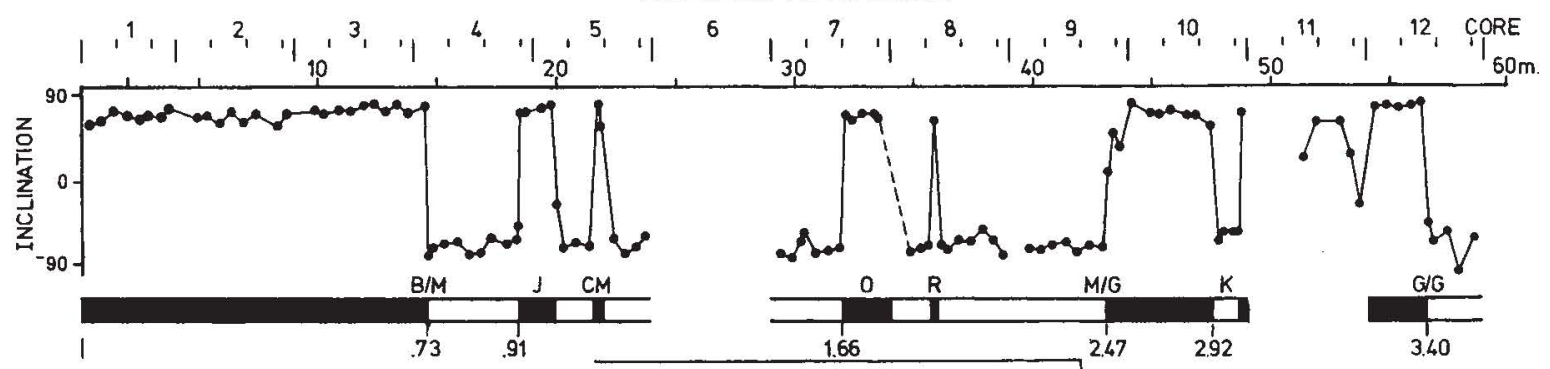

Fig. 2 Magnetic record for Site 552A. Demagnetized inclinations are shown only for apparently undisturbed parts of the cores (the data from core 11 suggest that some unrecognized disturbance may be present).

The upper $40 \mathrm{~m}$ of the section comprises alternating units of white and dark grey colour. In the white intervals, the $>150-\mu \mathrm{m}$ fraction consists almost exclusively of foraminifera; in the dark intervals angular sand-sized rock fragments predominate although sufficient benthic foraminifera for isotopic analysis are present at almost every horizon examined. The darkcoloured intervals containing ice-rafted material are visually clear and also show unmistakably in a record of carbonate content (typically between 80 and $90 \%$ in the white layers and $10-40 \%$ in the dark layers).

We have made isotope analyses at $10-\mathrm{cm}$ intervals over the interval from well below the first ice-rafting layer, through to the recent sediment. Only core 6 was excluded from analysis because it was very severely disturbed by coring. Three species were used: Globocassidulina subglobosa, Uvigerina peregrina and Planulina wuellerstorfi. In Figs 3 and 4 data are presented using the previously established 'correction factors' to relate the oxygen isotope values obtained for $G$. subglobosa and $P$. wuellerstorfi to the equilibrium value which is thought to be given by Uvigerina spp. ${ }^{4,5}$. Carbon isotope values are related to $P$. wuellerstorfi rather than to Uvigerina because this procedure provides a good estimate of the ${ }^{13} \mathrm{C}$ content of ocean dissolved $\mathrm{CO}_{2}$ (refs 6,7).

Samples for palaeomagnetic analysis were taken approximately every $25 \mathrm{~cm}$, avoiding sediment that showed any sign of disturbance. Only orientation with respect to the vertical axis was preserved so that the inclination component is used to infer polarity at this high-latitude site. The natural remanent magnetization (NRM) was measured on a two-axis cryogenic magnetometer ${ }^{8}$ both before and after alternating-field demagnetization at $10-30 \mathrm{mT}$. NRM intensities are typically of the order $10^{-2} \mathrm{~A} \mathrm{~m}^{-1}$ in the upper $45 \mathrm{~m}$ of the section, decreasing to about $10^{-3} \mathrm{~A} \mathrm{~m}^{-1}$ in the lower part. Measured inclination data are shown in Fig. 2. Inclinations are generally well-grouped near to the expected dipole value $\left(71^{\circ}\right.$, positive for normal and negative for reversed) for the latitude of the site, indicating that a reliable record of the geomagnetic field has been obtained to the base of the Gauss normal magnetochron. The lower boundary of the Olduvai subchron is unfortunately obscured by disturbance at the break between successive cores, while the Mammoth subchron is unclear, probably lying in a slightly disturbed section of core 11 .

Analyses of the carbonate content of the sediment have also been made at $10-\mathrm{cm}$ intervals through the upper $59 \mathrm{~m}$ of the section. In this part of the North Atlantic, carbonate content is controlled chiefly by variations in the influx of non-carbonate material transported by ice ${ }^{9}$. Changing carbonate production also has a major role, while carbonate dissolution has little impact at such shallow water depths in the North Atlantic.

The samples taken for stable isotope analysis were also used for quantitative nannofossil studies; here we show (Fig. 4) only those nannofossil data which have a bearing on the biostratigraphical position of the early ice-rafting horizon.

Figure 3 shows the oxygen isotope and carbonate data for the upper five cores, together with the oxygen isotope record of core V28-238 (ref. 4) for comparison. Both records are plotted linearly with respect to depth in sediment between magnetic reversals. Since it has been established that the sediment in V28-238 accumulated at a fairly regular rate ${ }^{10}$, the axis

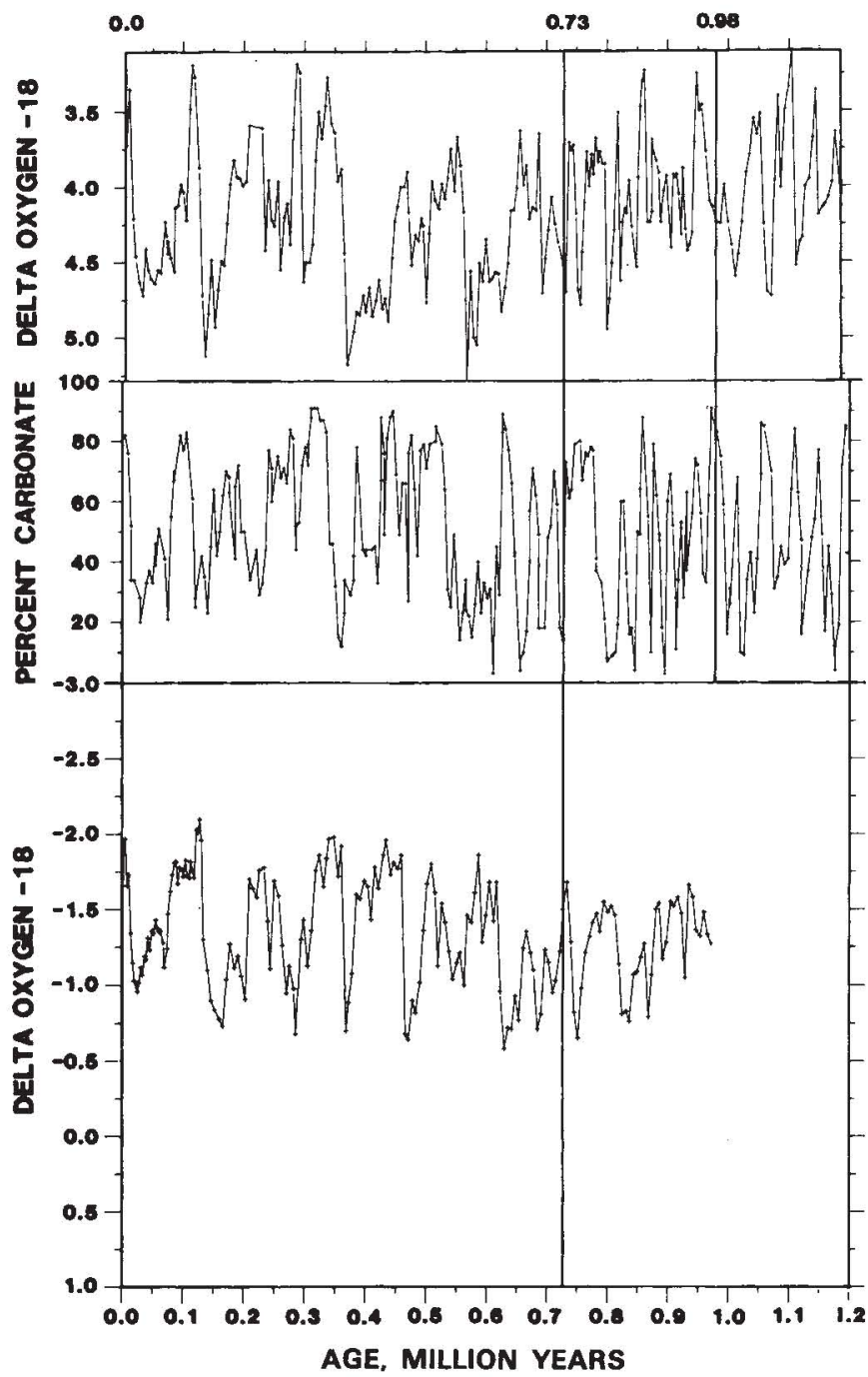

Fig. 3 Top: Oxygen isotope record of Site 552A cores 1-5. The plotting scale is linear between magnetic reversal horizons. Middle: carbonate content in the same interval; low carbonate content implies dilution by ice-rafted material. Bottom: oxygen isotope record of Pacific core V28-238 (ref. 4) for comparison. Vertical lines indicate the horizons used for time control: top (zero age), base Bruhnes normal chron ( $0.73 \mathrm{Myr})$, base Jaramillo subchron $(0.98 \mathrm{Myr})$.

is shown as an approximate age scale calibrated on the basis of the single magnetic reversal in this core. Thus the comparison shows that there have been quite marked accumulation rate variations in DSDP 552A. This is hardly surprising in view of the lithological variations that are evident. Nonetheless the oxygen isotope record of Site $552 \mathrm{~A}$ is complete to the extent of preserving every isotope stage.

In Figure 4, the oxygen isotope data for the lower part of the sequence are shown and compared with the oxygen isotope data for piston core V28-179. (Figure 4 shows additional measurements that we have made in core V28-179. Note that the position 


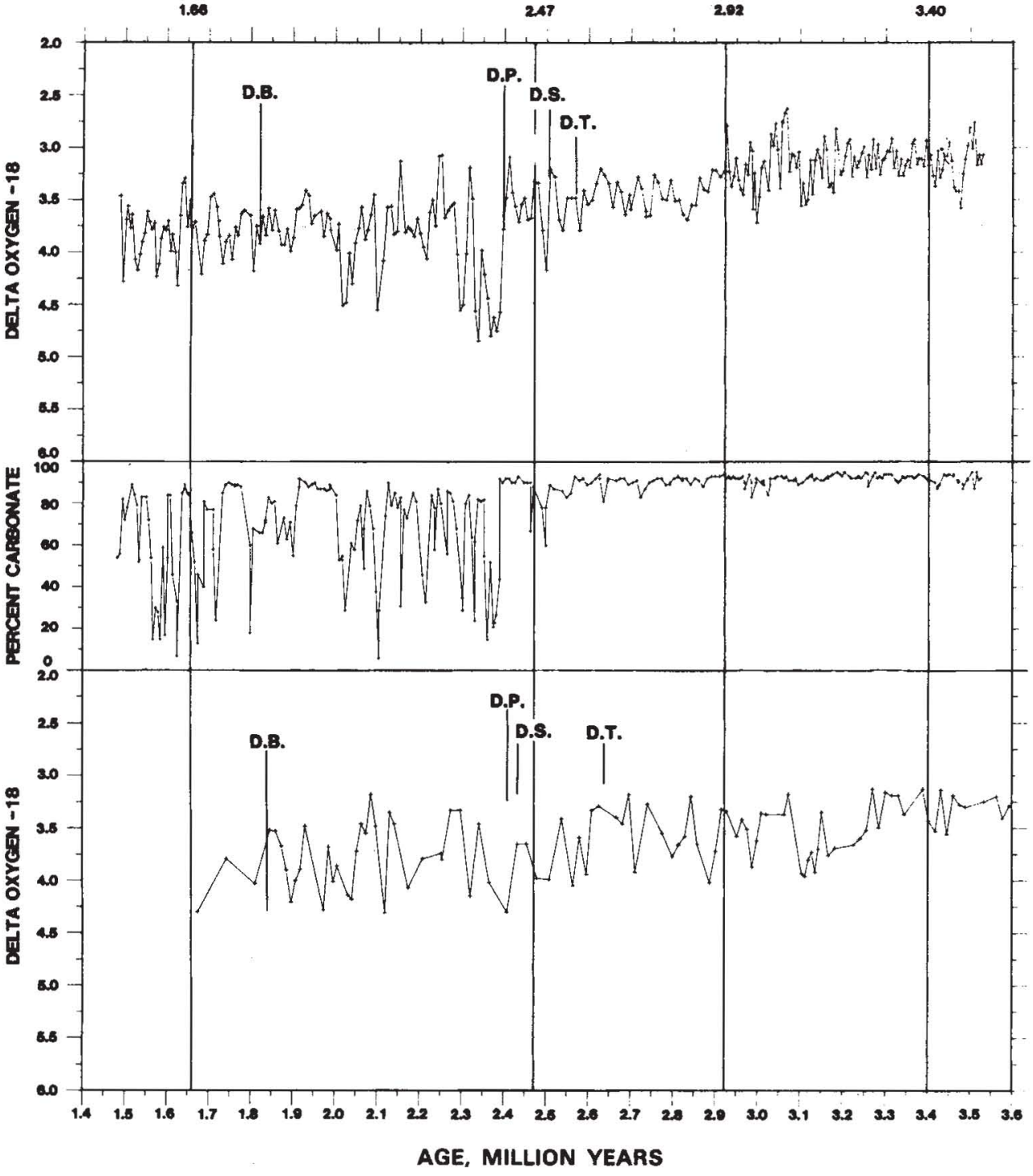

Fig. 4 Top: Oxygen isotope record of Site $552 \mathrm{~A}$ cores $7-12$. The plotting scale is linear between magnetic reversal horizons. Middle: carbonate content in same interval. Bottom: oxygen isotope record in Pacific core V28-179 (ref. 11) for comparison. Vertical lines show horizons used for time control: top Olduvai normal subchron (1.66 Myr), base Matuyama reversed chron $(2.47$ Myr), top Kaena reversed subchron (2.92 Myr), base Gauss normal chron (3.40 Myr). Nannofossil extinction horizons determined in both cores indicated by: DT, Discoaster tamalis; DS, D. surculus; DP, D. pentaradiatus; DB, D. brouweri. of the Gauss-Matuyama boundary was incorrectly printed in ref. 11; it was in fact located at $1,338 \mathrm{~cm}$, not $1,358 \mathrm{~cm}$.) Again, to facilitate comparison, the plotting scale for both records has been adjusted at magnetostratigraphic boundaries as indicated, so as to approximate an age scale using a palaeomagnetic time scale $^{12}$. Obviously the application of this age scale becomes less accurate far from the magnetic reversals. However, comparison between the two records is good considering the low accumulation rate, and relatively coarse sampling interval in V28-179, and many small-scale features can be correlated between the two. The amplitude of variation is substantially greater in Site $552 \mathrm{~A}$ than in V28-179. This is probably due to the effect of bioturbation in the Pacific core; since the accumulation rate of core V28-179 was only about $0.55 \mathrm{~cm} \mathrm{kyr}^{-1}$, one would expect climatic extremes lasting only a few thousand years to be severely degraded by bioturbation.

The series of nannofossil extinction data shown in Fig. 4 have also been determined quantitatively in core V28-179 (ref. 13) and their ages estimated. Using these estimates, the average accumulation rate over the pre-ice-rafting interval in Site $552 \mathrm{~A}$ may be estimated at approximately $1.7 \mathrm{~cm} \mathrm{kyr}^{-1}$, surprisingly close to the average for the upper part, $1.8 \mathrm{~cm} \mathrm{kyr}^{-1}$ (although the rate has certainly varied over short intervals during the intense climatic fluctuations of the past few million years). Palaeomagnetic stratigraphy and nannofossil stratigraphy in this site give identical estimates for the age of the first major northern hemisphere glacial event about 2.37 Myr.
It is clear from an examination of Figs 3 and 4 that there is a remarkable correspondence between the records of oxygen isotopic composition in the foraminifera, and carbonate content, back to about $2.4 \mathrm{Myr}$. This is not particularly surprising since both are clearly causally related to glaciation. However, it is worth noting that if the late Pliocene isotopic fluctuations were attributed to glaciation in Antarctica, one would not expect the influx of ice-rafted debris during the glaciation at 2.4 Myr to be as dramatic as that observed in the last glacial, whereas this is what we observe in Site 552A. A brief ice-rafting episode, coinciding with positive ${ }^{18} \mathrm{O}$ values, is observed at about $2.5 \mathrm{Myr}$. Prior to $2.5 \mathrm{Myr}$, the influx of ice-rafted debris is minute and has little impact on the record of carbonate content. Presumably such glaciation as may have occurred before that time did not give rise to extensive calving of icebergs into the North Atlantic.

If we compare the isotopic composition of benthonic foraminifera at the level of the first glacial maximum at $2.37 \mathrm{Myr}$ with values in glacial levels in the upper part of the sequence, it becomes apparent that the early event represents a truly glacial interval, with an ice volume similar to maxima during the middle Pleistocene. This must, for instance, be correlative with a fully glacial environment in Britain although obviously the actual ice-margin positions cannot be determined from these data.

Other data relating to a major climatic threshold being crossed at this time comes from the Netherlands and New Zealand. In the Netherlands, Zagwijn ${ }^{14}$ has shown that there was a complete 
C-13 DATA DSDP552A and V28-179

Fig. 5 Carbon isotope records for Site 552A cores 7-12 (top) and Pacific core V28-179 (bottom). Both are plotted on the same ${ }^{13} \mathrm{C}$ scale and represent estimates of the ${ }^{13} \mathrm{C}$ contents of intermediate depth $(2,311 \mathrm{~m})$ water in the North Atlantic (above) and of deep $(4,509 \mathrm{~m})$ water in the equatorial Pacific (below). Today there is an observed difference of a little over $1 \%$ which reflects the fact that ocean deep waters are ventilated in the North Atlantic.

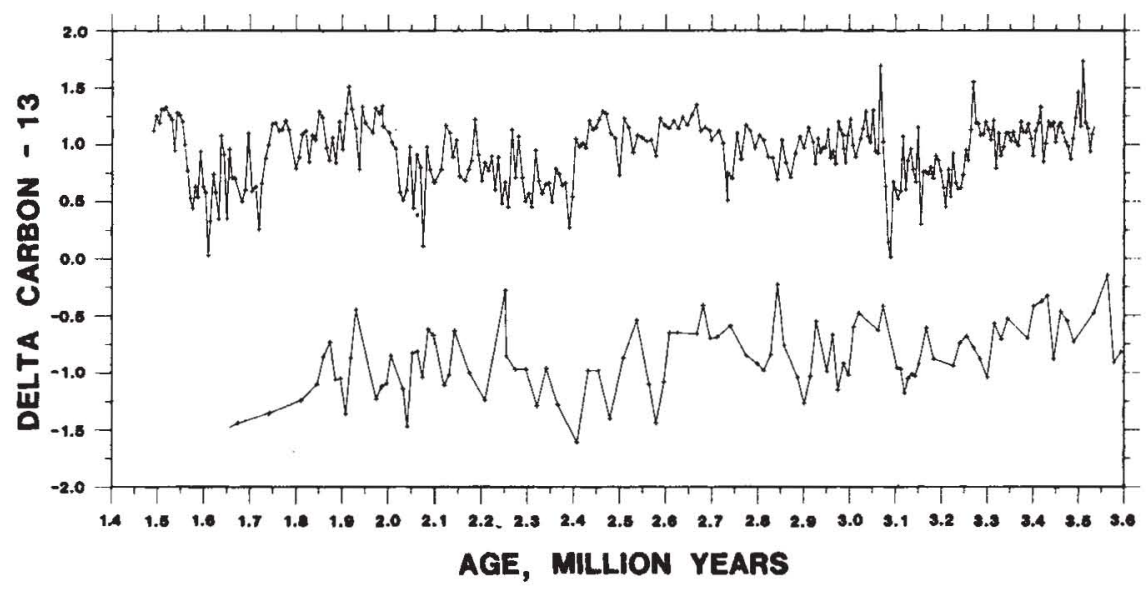

overturn in vegetational type just after the Gauss-Matuyama boundary; indeed he regards this as representing the PliocenePleistocene boundary. In New Zealand, Stipp and others ${ }^{15}$ showed that there was a major drop in sea level between about 2.4 and $2.6 \mathrm{Myr}$; again, they correlated this event, which they interpreted as the first glacio-eustatic fall in sea level, with the Pliocene-Pleistocene boundary. We disagree with these opinions, only because we consider it well established that the Pliocene-Pleistocene boundary at the newly proposed stratotype at Vrica $^{16}$, as well as at previous Calabrian sections, has a much younger age of about $1.6 \mathrm{Myr}$ (ref. 17). If the boundary were selected on the basis of a significant climatic event rather than on historical precedent, it might appropriately be re-positioned so as to coincide with the climatic change about $2.4 \mathrm{Myr}$, but we do not recommend such an approach to the definition of geological boundaries.

The data shown in Fig. 4 also indicate that there was considerable climatic variability, somewhere on the globe, even before $2.5 \mathrm{Myr}$. It is well established that glaciation in Iceland occurred as early as 3.1 Myr (ref. 18) although recent work suggests that glaciation did not reach sea level in Iceland until about $2.0 \mathrm{Myr}$ (ref. 19) and there is also evidence for glaciation in the Sierra Nevada, California, at about the same time ${ }^{20}$. However, palaeooceanographic conditions on Rockall Bank do not suggest severe climates in North-west Europe. Occasional grains of ice-rafted debris do occur, and the nannofossil floras certainly show marked variation, but the scale of variation was much less before $2.4 \mathrm{Myr}$ than it was after the event at that time.

Figure 5 shows the carbon isotope records for DSDP 552A and V28-179. The data are plotted on the same isotope scale and the same species-dependent correction factors have been made to both. The persistent isotopic difference between the two records of over $1 \%$ indicates a continuing situation in which the water bathing the sea floor on Rockall was isotopically heavier for ${ }^{13} \mathrm{C}$ than deep water in the Pacific, as is the case today. This difference reflects the difference between newlyformed, oxygen rich North Atlantic deep water (NADW) and older, oxygen-depleted deep Pacific water ${ }^{21,22}$. We (and also Blanc et $a l^{23}$ ) disagree with Keigwin's deduction ${ }^{24}$ that the formation of NADW only began with the closing of the Panama Straits at 3.0 Myr, although this event may well have affected the contribution that this water mass made to the deep water of the Caribbean deep waters that were the topic of Keigwin's study ${ }^{24}$.

In the upper part of the section, it is clear that DSDP Site $552 \mathrm{~A}$ preserves the whole of the standard oxygen isotope record of the past million years. Although the fine structure of many stages is obscure, every single stage is present. By comparison, we note that the stratigraphically longest piston core from the North Atlantic, core Kane 708-7 (ref. 9), extends only to Stage 17 at about $0.6 \mathrm{Myr}$. For the earlier record, only DSDP Site 116 , recently re-investigated from the palaeoclimatic point of view ${ }^{25}$, was previously available. Site 116 was recovered by conventional rotary drilling and the sediment was so disturbed that glacial and non-glacial materials are intermixed, precluding any high-resolution studies being made. It is to be hoped that the new technique of ${ }^{13} \mathrm{C}$ analysis in the organic carbon portion of the sediment, pioneered in Site 116 (ref. 25), will be applied to Site $552 \mathrm{~A}$. We believe that the material recovered in Site $552 \mathrm{~A}$ is ideal for detailed studies of climatic evolution in the ocean adjacent to the north-west European region where the Plio-Pleistocene continental record is best known.

N.J.S. thanks NERC for support and Mike Tabecki for laboratory assistance. D.V.K. tanks NSF for support, LamontDoherty Geological Observatory contribution no. 3552.

Received 22 August; accepted 31 October 1983.

1. Berggren, A. A. Init. Rep. DSDP 12, 953-963 (1972).

2. Backman. J. Stockh Contr. Geol 32, 113-137 (1979).

3. Prell, W. L. et al. Init. Rep. DSDP 68, 5-6 (1982).

4. Shackleton, N. J. \& Opdyke, N. D. Quat. Res. 3, 39-55 (1973)

5. Shackleton, N. J. Coll int. Cent. natn. Rech. Scient. 219, 203-210 (1974).

. Graham, D. W., Corliss, B. H., Bender, M. L. \& Keigwin, L. D. Jr Mar. Micropalaeont. 6, 483-497 (1981).

7. Duplessy, J.-C. et al. Quat. Res. (in the press)

8. Goree, W. S. \& Fuller, M. Rev. Geophys. Space Phys. 14, 591-608 (1976).

9. Ruddiman, W. F. \& McIntyre, A. Mem. Geol. Soc. Am. 145, 111-146 (1976).

10. Imbrie, J. et al in Milankovich and Climate (eds Berger, A. L. et al) (Reidel, Dordrecht, in the press).

11. Shackleton, N. J. \& Opdyke, N. D. Nature 270, 216-219 (1977).

12. Berggren, W. A., Kent, D. V. \& van Couvering, J. Geol. Soc. Lond. Spec, Publ. (ed. Snelling, N. L.) (in the press).

13. Backman, J. A. \& Shackleton, N. J. Mar. Micropalaeont. 8, 141-170 (1983).

14. Zagwijn, W. Boreas 3, 75-97 (1974).

15. Stipp, J. J., Chappell, J. H. A. \& McDougall, I. Am. J. Sci. 265, 462-474 (1967).

16. Selli, R. et al. Giom Geol 42, 181-204 (1977).

17. Backman, J., Shackleton, N. J. \& Tauxe, L. Nature 304, 156-158 (1983).

18. McDougall, I. \& Wensink, H. Earth planet. Sci. Lett. 1, 232-236 (1966)

19. Albertsson, K. J. Náttúrufraedingurinn 48 , 1-8 (1978).

20. Curry, R. R. Science 154, 1121-1142 (1966).

21. Duplessy, J.-C. thesis, Univ, Paris VI (1972).

22. Kroopnick, P., Deuser, W. G. \& Craig, H. J. geophys. Res. 75, 7668-7671 (1970)

23. Blanc, P. L., Rabussier, D., Vergnaud-Grazzini, C. \& Duplessy, J.-C. Nature 283, 553-555 (1980).

24. Keigwin, L. D. Science 217, 350-353 (1982).

25. Blanc, P. L., Fontugne, M. R. \& Duplessy, J.-C. Palaeogeogr. Palaeoclimatol. Palaeoecol. 42, 211-224 (1983). 